\title{
Invasive group A streptococcal soft tissue infection and the streptococcal toxic shock like syndrome
}

\author{
Frankie OG Fraulin MD, Martin J Giuffre MD FRCSC, David D Campbell MD FRCSC, \\ Gary W Lobay MD FRCSC, David C Edwards MD FRCSC \\ Division of Plastic Surgery, Department of Surgery, University of Alberta Hospitals, Edmonton, Alberta
}

\begin{abstract}
FOG Fraulin, MJ Giuffre, DD Campbell, GW Lobay, DC Edwards. Invasive group A streptococcal soft tissue infection and the streptococcal toxic shock like syndrome. Can J Plast Surg 1995;3(1):30-34. A recent increase in the number of patients with severe group A streptococcal soft tissue infections and the streptococcal toxic shock like syndrome (STSLS) in Edmonton sparked the interest to review eight cases that occurred between March 1991 and December 1993, including two patients after cosmetic surgery. These cases were felt to be sporadic and not linked. Four of the eight patients (age range 25 to 64 years), including one patient following upper blepharoplasties, developed invasive infection without shock. These patients presented one to seven days after the initiating event with only mild fever, but severe pain and localized erythema and swelling in the affected area which progressed quickly with the formation of bullae. Two streptococcal specimens were serotyped as M1 and contained streptococcal pyrogenic exotoxins (SPE) A and B. Management included surgical debridement, penicillin, and clindamycin (interferes with Mprotein and toxin production). All four patients recovered. The other four patients, including one patient following rhytidectomy, (age range 45 to 83 years) were much more ill and developed STSLS. They rapidly developed septic shock within 12 to $24 \mathrm{~h}$ and progressed to multiorgan involvement despite surgical debridement. One streptococcal specimen was serotyped as M1 and positive for SPE A and B, another specimen as M12 and positive for SPE B, and another specimen as M-nontypable and positive for SPE B. Two patients died within five days of presentation. The other two patients recovered following lengthy hospitalization, reconstructive surgery and rehabilitation.
\end{abstract}

Key words: Group A streptococcus, M protein, Necrotizing cellulitis, Rhytidectomy, Streptococcal pyrogenic exotoxins, Streptococcal toxic shock like syndrome

\section{Infection envahissante des tissus mous par le streptocoque du groupe A et syndrome de pseudo-choc toxique streptococcique.}

RÉSUMÉ : La récente hausse du nombre de patients atteints d'infection grave des tissus mous à streptocoque du groupe A et de syndrome de pseudo-choc toxique streptococcique à Edmonton a motivé l'auteur à passer en revue huit cas survenus entre mars 1991 et décembre 1993, y compris deux patients ayant subi une chirurgie esthétique. Ces cas ont été jugés sporadiques et indépendants les uns des autres. Quatre patients sur huit (âge : 25 à 64 ans) y compris un patient ayant subi une blépharoplastie ont développé une infection envahissante sans choc. De un à sept jours après l'incident déclencheur, ces patients n'ont présenté qu'une légère fièvre, mais une douleur intense et un érythème localisé, ainsi qu'un enflure de la zone atteinte, qui ont rapidement progressé vers la formation de bulles. Deux spécimens de streptocoques ont été sérotypés M-1 et renfermaient des exotoxines streptococciques pyrogènes (ESP) A et B. Le traitement a consisté en un débridement chirurgical, l'administration de pénicilline et de clindamycine (qui interfère avec la production de protéine-M et de toxines). Les quatre patients ont récupéré. Les quatre autres patients, $\mathrm{y}$ compris une patiente ayant subi une rhytidectomie (âge : 45 - 83 ans), ont été beaucoup plus malades et ont développé un syndrome de choc toxique. Ils sont rapidement entrés en choc septique dans les 12 à 24 heures et ont progressé vers une atteinte pluriorganique malgré le débridement chirurgical. Un spécimen de streptocoque a été sérotypé M-1 et était positif à l'égard des ESP A et B. Un autre spécimen était M-12 et positif à l'égard de l'ESP B et un autre spécimen non M-typable et positif à l'égard de l'ESP B. Deux patients sont morts dans les cinq jours qui ont suivi leur consultation. Les deux autres patients ont récupéré après une hospitalisation prolongée, une chirurgie de reconstruction et une réadaptation.

$\mathrm{G}$ roup A streptococcus is found around the world; its ecological niche is the skin and mucous membranes of humans (1). There are more than 80 types of this organism based on a cell wall constituent known as the M-protein, which is also one of its key virulence factors. Group A streptococcus can cause a variety of illnesses ranging from mild

Correspondence and reprints: Dr Frankie Fraulin, \#102 - 11660 79 Avenue, Edmonton, Alberta T6G 0P7. Telephone (403) 437-6845 conditions such as pharyngitis to less common, but more destructive infections, such as necrotizing cellulitis (2).

In the 1800 s, there was a worldwide pandemic of streptococcal infections. From 1885 to the early 1980 s, a general decrease in the number of infections occurred, even before the advent of antibiotics. This decline was thought to be due to cleaner and less crowded living conditions (3). Beginning in 1985, an increasing number of outbreaks of acute rheumatic 


\section{TABLE 1: Case definition: streptococcal toxic shock syndrome}

1. Isolation of group A streptococci (Streptococcus pyogenes)

A. From a normally sterile site (eg, blood, cerebrospinal, pleural or peritoneal fluid, tissue biopsy, surgical wound, etc)

B. From a nonsterile site (eg, throat, sputum, vagina, superficial skin lesion, etc)

\section{Clinical signs of severity}

A. Hypotension: systolic blood pressure $\leq 90 \mathrm{mmHg}$ in adults or $<5$ th percentile for age in children and

B. at least two of the following signs

1. Renal impairment: creatinine $\geq 177 \mu \mathrm{mol} / \mathrm{L}$ ( $\geq 2 \mathrm{mg} / \mathrm{dL}$ ) for adults or greater than or equal to twice the upper limit of normal for age. In patients with preexisting renal disease, $a \geq 2$ fold elevation over the baseline level.

2. Coagulopathy: platelets $\leq 100 \times 10^{9} / \mathrm{L}\left(\leq 100,000 / \mathrm{mm}^{3}\right)$ or disseminated intravascular coagulation defined by prolonged clotting times, low fibrinogen level, and the presence of fibrin degradation products.

3. Liver involvement: alanine aminotransferase (AST), aspartate aminotransferase (AST) or total bilirubin levels greater than or equal to twice the upper limit of normal for age. In patients with preexisting liver disease, a $\geq 2$-fold elevation over the baseline level.

4. Adult respiratory distress syndrome defined by acute onset of diffuse pulmonary infiltrates and hypoxemia in the absence of cardiac failure, or evidence of diffuse capillary leak manifested by acute onset of generalized edema, or pleural or peritoneal effusions with hypoalbuminemia.

5. A generalized erythematous macular rash that may desquamate.

6. Soft-tissue necrosis, including necrotizing fasciitis or myositis, or gangrene.

From reference 2, with permission

TABLE 2: Invasive infection without shock $(n=4)$

\begin{tabular}{|c|c|c|c|c|c|c|c|}
\hline ID Sex/age & Initiating event & Onset & Initial signs & Initial lab & Diagnosis & Clinical course & Outcome \\
\hline $\begin{array}{l}\text { (1) F/64 years } \\
\text { Admit: Mar 24, } \\
1991\end{array}$ & $\begin{array}{l}\text { Upper lid blepha- } \\
\text { roplasties }\end{array}$ & 2-3 days & $\begin{array}{l}\text { Pain. Swelling and } \\
\text { erythema. Con- } \\
\text { fused. T: } 36.2^{\circ} \mathrm{C}\end{array}$ & $\begin{array}{l}\text { WBC } 38.2 \times 10^{9} / \mathrm{L} \\
13 \% \text { bands } \\
\text { Na: } 118 \mathrm{mmol} / \mathrm{L}\end{array}$ & $\begin{array}{l}\text { Wound Gram } \\
\text { stain and cul- } \\
\text { ture }\end{array}$ & $\begin{array}{l}\text { Periorbital cellulitis } \\
\text { and necrosis. Cor- } \\
\text { neal abrasion }\end{array}$ & $\begin{array}{l}\text { Debridement. } \\
\text { 46-day hospital } \\
\text { stay }\end{array}$ \\
\hline $\begin{array}{l}\text { (2) M/40 years } \\
\text { Admit: July } 29 \\
1991\end{array}$ & $\begin{array}{l}\text { Fall on leg while } \\
\text { jogging - } \\
\text { abrasion }\end{array}$ & 7 days & $\begin{array}{l}\text { Pain. Swelling and } \\
\text { erythema. Mild fe- } \\
\text { ver. T: } 38.2^{\circ} \mathrm{C}\end{array}$ & WBC: $11.6 \times 10^{9} / \mathrm{L}$ & $\begin{array}{l}\text { Wound Gram } \\
\text { stain and cul- } \\
\text { ture }\end{array}$ & $\begin{array}{l}\text { Necrotizing fasciitis } \\
\text { and cellulitis }\end{array}$ & $\begin{array}{l}\text { Multiple debride- } \\
\text { ments. Skin graft- } \\
\text { ing. } \\
\text { 32-day hospital } \\
\text { stay }\end{array}$ \\
\hline $\begin{array}{l}\text { (3) M/45 years } \\
\text { Admit: July } 13 \\
1993\end{array}$ & $\begin{array}{l}\text { Horse kick to } \\
\text { knee - abrasion }\end{array}$ & 1 day & $\begin{array}{l}\text { Pain. Swelling and } \\
\text { erythema. Mild fe- } \\
\text { ver. T: } 37.9^{\circ} \mathrm{C}\end{array}$ & WBC: $12 \times 10^{9} / \mathrm{L}$ & $\begin{array}{l}\text { Wound Gram } \\
\text { stain and cul- } \\
\text { ture }\end{array}$ & $\begin{array}{l}\text { Septic arthritis. Ne- } \\
\text { crotizing cellulitis }\end{array}$ & $\begin{array}{l}\text { Multiple debride- } \\
\text { ments. Skin graft- } \\
\text { ing. } \\
\text { 18-day hospital } \\
\text { stay }\end{array}$ \\
\hline $\begin{array}{l}\text { (4) F/25 years } \\
\text { Admit: Dec } 6 \\
1993\end{array}$ & $\begin{array}{l}\text { IV cocaine injec- } \\
\text { tion }\end{array}$ & 3 days & $\begin{array}{l}\text { Pain. Swelling and } \\
\text { erythema. Mild fe- } \\
\text { ver. T: } 38^{\circ} \mathrm{C}\end{array}$ & $\begin{array}{l}\text { WBC } 17.6 \times 10^{9} / \mathrm{L} \\
37 \% \text { bands }\end{array}$ & $\begin{array}{l}\text { Blood Gram } \\
\text { stain and cul- } \\
\text { ture }\end{array}$ & $\begin{array}{l}\text { Septic thrombo- } \\
\text { phlebitis. Necrotiz- } \\
\text { ing cellulitis }\end{array}$ & $\begin{array}{l}\text { Debridement. Skin } \\
\text { grafting. 17-day } \\
\text { hospital stay }\end{array}$ \\
\hline
\end{tabular}

F Female; M Male; Na Sodium; T Temperature; WBC White blood cell count

fever were being reported (4). Cone et al (5) first introduced the term 'streptococcal toxic shock like syndrome' (STSLS) after they published a report in 1987 of two patients who suffered from an infection with many features similar to the staphylococcal toxic shock syndrome (5). Since then, there have been many reports of invasive infection and toxic shock due to this organism $(1,5-15)$.

In January 1993, the Centers for Disease Control and Prevention in Atlanta developed a case definition for this new syndrome (Table 1) which includes the isolation of Streptococcus pyogenes, shock, and specific evidence of multiorgan involvement (2).

An increased number of severe group A streptococcal soft tissue infections came to the attention of the plastic surgery service recently with five cases in the last six months of 1993. This sparked the interest to review eight cases of this serious illness that occurred between March 1991 and December
1993. Two of these cases occurred in patients who had undergone elective cosmetic operations.

Four patients suffered invasive infection without shock. The other four patients met the strict criteria for STSLS. The charts were reviewed and five of the eight patients also had specimens serotyped by the National Centre for Streptococcus, located in Edmonton.

\section{INVASIVE INFECTION WITHOUT SHOCK}

The four patients who developed invasive infection without shock ranged in age from 25 to 64 years (Table 2). The initiating event was cosmetic blepharoplasties in one patient, minor trauma in two patients, and intravenous cocaine injection in one patient. All patients were previously healthy with no underlying medical problems. The time between the initiating event and the onset of symptoms varied from one to seven days. The most common presentation was severe pain 
TABLE 3: Streptococcal toxic shock like syndrome $(n=4)$

\begin{tabular}{|c|c|c|c|c|c|c|c|c|}
\hline ID sex/age & $\begin{array}{l}\text { Initiating } \\
\text { event }\end{array}$ & Onset & Initial signs & Initial lab & $\begin{array}{l}\text { Time to } \\
\text { shock }\end{array}$ & Diagnosis & Clinical course & Outcome \\
\hline $\begin{array}{l}\text { (5) F/56 years } \\
\text { Admit: June } 6 \\
1991\end{array}$ & Facelift & 2 days & $\begin{array}{l}\text { Presented in sep- } \\
\text { tic shock }\end{array}$ & $\begin{array}{l}\text { WBC: } \\
2.6 \times 10^{9} / \mathrm{L}\end{array}$ & $\begin{array}{l}\text { Presented } \\
\text { in septic } \\
\text { shock }\end{array}$ & $\begin{array}{l}\text { Blood Gram } \\
\text { stain and } \\
\text { culture }\end{array}$ & $\begin{array}{l}\text { Coagulopathy. Liver } \\
\text { involvement. ARDS. } \\
\text { Necrotizing cellulitis }\end{array}$ & $\begin{array}{l}\text { Multiple debride- } \\
\text { ments. Skin graft- } \\
\text { ing. Survival. ICU: } \\
54 \text { days }\end{array}$ \\
\hline $\begin{array}{l}\text { (6) M/45 years } \\
\text { Admit: Oct } 8 \text {, } \\
1993\end{array}$ & $\begin{array}{l}\text { Fell on } \\
\text { knee at } \\
\text { work - } \\
\text { abrasion }\end{array}$ & 5 days & $\begin{array}{l}\text { Pain. Swelling } \\
\text { and erythema. } \\
\mathrm{T}: 36.3^{\circ} \mathrm{C}\end{array}$ & $\begin{array}{l}\text { WBC } \\
9.8 \times 10^{9} / \mathrm{L} \\
47 \% \text { bands }\end{array}$ & $6 \mathrm{~h}$ & $\begin{array}{l}\text { Blood Gram } \\
\text { stain and } \\
\text { culture }\end{array}$ & $\begin{array}{l}\text { Renal impairment. } \\
\text { Coagulopathy. Liver } \\
\text { involvement. Necro- } \\
\text { tizing fasciitis and } \\
\text { cellulitis }\end{array}$ & $\begin{array}{l}\text { Multiple debride- } \\
\text { ments. Skin graft- } \\
\text { ing and local flaps. } \\
\text { Survival. ICU: } 6 \\
\text { days }\end{array}$ \\
\hline $\begin{array}{l}\text { (7) M/83 years } \\
\text { Admit: Nov } 23 \\
1991\end{array}$ & $\begin{array}{l}\text { Fell on arm } \\
\text { at home - } \\
\text { abrasion }\end{array}$ & 7 days & $\begin{array}{l}\text { Swelling and ery- } \\
\text { thema. Confusion. } \\
\text { Fever. T: } 38.6^{\circ} \mathrm{C}\end{array}$ & $\begin{array}{l}\text { WBC: } \\
12.9 \times 10^{9} / \mathrm{L} \\
47 \% \text { bands }\end{array}$ & $24 \mathrm{~h}$ & $\begin{array}{l}\text { Wound } \\
\text { Gram stain } \\
\text { and culture }\end{array}$ & $\begin{array}{l}\text { Renal impairment. } \\
\text { Coagulopathy. Ne- } \\
\text { crotizing cellulitis. }\end{array}$ & $\begin{array}{l}\text { Debridement. } \\
\text { Death in } 3 \text { days }\end{array}$ \\
\hline $\begin{array}{l}\text { (8) F/67 years } \\
\text { Admit Dec } 24 \text {, } \\
1993 .\end{array}$ & $\begin{array}{l}\text { Unknown. } \\
\text { 'Flu like ill- } \\
\text { ness. }\end{array}$ & $\begin{array}{l}\text { Un- } \\
\text { known }\end{array}$ & $\begin{array}{l}\text { Pain. Swelling in } \\
\text { leg. Fever. } \\
\mathrm{T}: 40.1^{\circ} \mathrm{C}\end{array}$ & $\begin{array}{l}\text { WBC: } \\
8.4 \times 10^{9} / \mathrm{L} \\
46 \% \text { bands }\end{array}$ & $12 \mathrm{~h}$ & $\begin{array}{l}\text { Blood Gram } \\
\text { stain and } \\
\text { culture }\end{array}$ & $\begin{array}{l}\text { Renal impairment. } \\
\text { Coagulopathy. Liver } \\
\text { involvement. Myosi- } \\
\text { tis }\end{array}$ & $\begin{array}{l}4 \text { limb fasciotomy } \\
\text { and excision of ne- } \\
\text { crotic muscle. } \\
\text { Death in } 5 \text { days }\end{array}$ \\
\hline
\end{tabular}

ARDS Adult respiratory distress syndrome; F Female; M Male; ICU Intensive care unit; T Temperature; WBC White blood cell count

and localized swelling and erythema. Patients had a variable white blood cell count with an increase in immature cells or bands. A gram stain was helpful in making an early diagnosis, which was later confirmed by culture of group A $\beta$-hemolytic streptococcus alone. Despite appropriate therapy with penicillin, all wounds formed bullae and reddish purple discoloration that progressed to necrosis. Surgical debridement was required and clindamycin was added. These patients all recovered.

\section{STREPTOCOCCAL TOXIC SHOCK LIKE SYNDROME}

Patients that developed STSLS ranged in age from 45 to 83 years (Table 3 ).

The initiating event was rhytidectomy in one patient, minor trauma in two, and 'flu-like illness in the other. The onset and initial findings were very similar to the previous group. The difference was the rapid onset of septic shock within $24 \mathrm{~h}$ of presentation to the hospital. Resuscitation by fluids and inotropes was required in an intensive care unit (ICU) along with antibiotics and immediate debridement. All patients developed multiorgan involvement. Two patients died in ICU after several days. The other two patients survived after lengthy hospital stays.

One particular case (Case 5, Table 3) demonstrated many of the frightening features of the STSLS. A 56-year-old woman desired a facelift. Her past medical history included a full-thickness burn of her upper chest and neck that required skin grafting when she was a teenager. She underwent a standard rhytidectomy with SMAS plication and liposuction of the submental area and jowls without complication. No prophylactic antibiotics were given. She was doing well on the first day postoperatively with minimal bruising and swelling.

That same night, her husband contacted the surgeon involved stating that his wife was having severe pain and was

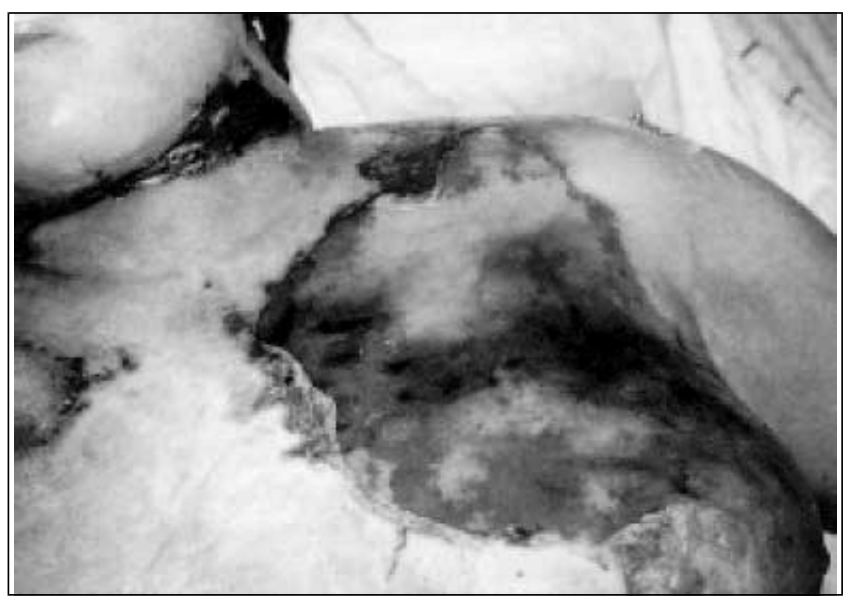

Figure 1) Rhytidectomy - initial presentation. Patient presented in septic shock 40 h post rhytidectomy. There is necrosis of areas on the neck and chest with advancing purplish discoloration of her anterior chest wall

becoming confused. On arrival to the hospital she was in florid septic shock and examination showed a black, necrotic area on her neck with advancing edematous, purplish discoloration of her anterior chest wall (Figure 1). She was immediately stabilized with airway control, fluids, inotropes and debridement of the necrotic areas. An initial Gram stain of the blood showed numerous Gram-positive cocci in chains, which was confirmed at $24 \mathrm{~h}$ to be group A streptococcus.

The broad spectrum antibiotics were discontinued and she was started on clindamycin. Progression to multiorgan involvement occurred including: coagulopathy and disseminated intravascular coagulation (platelets: $55 \times 10^{9} / \mathrm{L}$, prothrombin time $15.6 \mathrm{~s}$, partial thromboplastin time $58.9 \mathrm{~s}$, fibrinogen degradation products greater than 40); liver involvement (aspartate aminotransferase [AST] $135 \mathrm{U} / \mathrm{L}$; total bilirubin $43 \mu \mathrm{mol} / \mathrm{L}$ ); and eventually adult respiratory dis- 


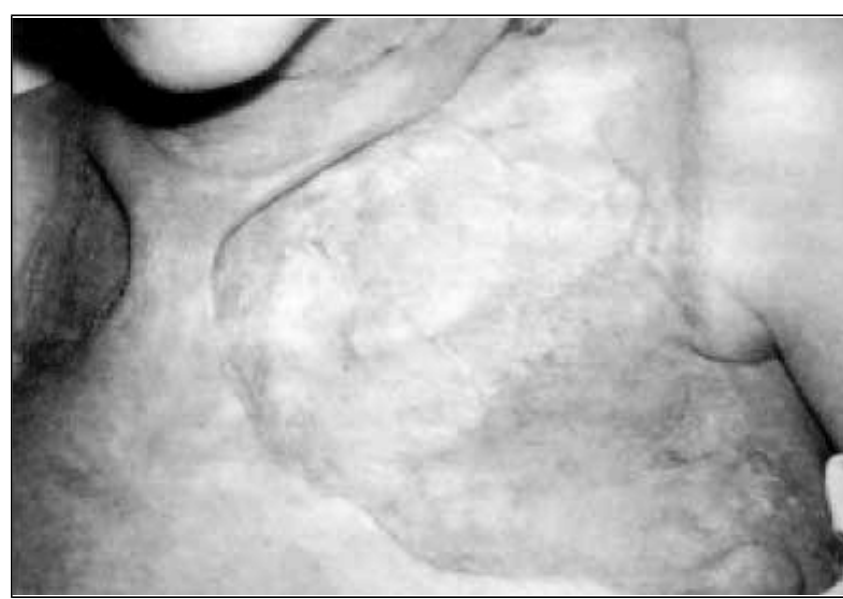

Figure 2) Rhytidectomy - after skin grafting. The main areas involved were the sites of her previous burn scar over the anterior chest wall. Skin grafts were later placed on the debrided areas

tress syndrome (bilateral diffuse pulmonary infiltrates, hypoxemia). During her 56-day stay in the ICU, she also developed complications associated with this setting including line sepsis, pneumonia, hyponatremia, diarrhea and oral candidiasis.

The main sites involved with the infection were the sites of her previous burn scar over the anterior chest wall and lower neck. Skin grafts were later placed on the debrided areas (Figure 2). Although she survived this severe illness, she required a great deal of rehabilitation and psychological counselling.

\section{DISCUSSION}

There has been an increase in severe streptococcal infections in Edmonton over the past two years. These cases were sporadic and not linked. We believe this is also the first report of the toxic shock like syndrome in a patient following a cosmetic procedure. Whether this increase is spurious and of limited importance or whether it is heralding a return to the pattern of the 1800s is speculative at this time (4). A recent report of a cluster of four group A wound infections on the same surgical service failed to find any relationship between infections (16). Incidence rates for these conditions are difficult to determine because group A streptococcal infections are not routinely reported to public health officials (10).

This recent change is thought to be due to a shift in the predominant $\mathrm{M}$ type protein and pyrogenic exotoxin produced. Because these serotypes and toxins have been uncommon for at least the past 50 years, this has resulted in a highly susceptible population that lacks the specific antibodies required to fight this organism $(1,2,4)$. The M-protein forms fibrils that project from the cell wall. Its antiphagocytic effect is one of the organism's key virulence factors, due to its ability to prevent opsonization by the complement system $(1,12)$. Of the five patients serotyped, three patients were Ml, one patient M12 and one patient was not M-typable (Table 4). This is consistent with the National Centre for Streptococcus data that found serotypes M1, M12 and M4 to be the types most frequently encountered in serious infections over the past
TABLE 4: Serology and exotoxins

\begin{tabular}{llll} 
ID & $\begin{array}{l}\text { Invasive or } \\
\text { toxic shock }\end{array}$ & Serotype & $\begin{array}{l}\text { Streptococcal } \\
\text { pyrogenic } \\
\text { exotoxin }\end{array}$ \\
\hline (3) $45 \mathrm{M}$ & Invasive & $\mathrm{M} 1, \mathrm{~T}^{*}$ & $\mathrm{~A}$ and B \\
(4) $25 \mathrm{~F}$ & Invasive & $\mathrm{M} 1, \mathrm{~T} 1$ & $\mathrm{~A}$ and B \\
(5) $56 \mathrm{~F}$ & Toxic shock & $\mathrm{M} 12, \mathrm{~T} 12$ & $\mathrm{~B}$ \\
(6) $45 \mathrm{M}$ & Toxic shock & $\mathrm{M} \mathrm{nt}^{\dagger}, \mathrm{T} 8$ & $\mathrm{~B}$ \\
(8) $67 \mathrm{~F}$ & Toxic shock & $\mathrm{M} 1, \mathrm{~T} 1$ & $\mathrm{~A}$ and B \\
\hline
\end{tabular}

F Female; $M$ Male

${ }^{*} T$ protein is a component of the cell wall not felt to be important in virulence of the organism; ${ }^{t}$ nt Nontypeable

three years (18). A recent review from Ontario found similar predominant M-types (14).

The streptococcal pyrogenic exotoxins (SPE) A, B and C are associated with severe infection. SPE-A shares $50 \%$ of its characteristics with staphylococcal enterotoxin $\mathrm{B}$, which is the toxin involved in staphylococcal toxic shock $(19,20)$. These toxins enhance the susceptibility to lethal shock (21). Of the five patients tested, three were positive for both $\mathrm{A}$ and $\mathrm{B}$, while two were positive for B only (Table 4).

One theory states that invasive disease may occur in people that lack the specific M-type antibody (1). Although patients infected in the past were predominantly diabetics, immunosuppressed or burn victims (22), seven of the eight patients reviewed were previously healthy. All patients had either only minor trauma or had undergone an elective surgical procedure. This agrees with other current reports of young, healthy people suffering from the streptococcal toxic shock like syndrome $(5-8,10,12,13)$; but there have also been outbreaks in nursing homes $(11,23)$. The most common presentation was the abrupt onset of severe pain and localized swelling and erythema and this also agrees with other reviews $(1,2,4)$. An ominous sign was the rapid progression of soft tissue infection. A Gram stain and culture of the wound or blood was important in making an early diagnosis.

This current theory also states that if the invading streptococcal strain also produces a pyrogenic exotoxin, and the patient does not have this specific antitoxin antibody, this can result in STSLS (1). Penicillin may be less effective in these major infections because of the slower growth rate of cocci under these conditions (Eagle effect) (24). Clindamycin is a potent inhibitor of protein synthesis and may interfere with toxin production and M-protein production $(24,25)$. It was found to be useful as an adjunct to, or as a substitute for, penicillin in most of our cases. Once toxic shock has developed, the morbidity and mortality increases considerably. Two of the four patients in this review died from multisystem organ failure. The mortality rate in other series has been as high as $30 \%$.

In conclusion, group A streptococcus is not always a mild or localized disease, but can produce a lethal fulminating illness. Appropriate treatment and survival depends on supportive measures, early surgical debridement and the use of antibiotics, particularly clindamycin. 


\section{REFERENCES}

1. Stevens DL. Invasive group A streptococcus infections. Clin Infect Dis 1992;14:2-13.

2. The working group on severe streptococcal infections. Defining the group A streptococcal toxic shock syndrome. JAMA 1993;269:390-1.

3. Katz AR, Morens DM. Severe streptococcal infections in historical perspective. Clin Infect Dis 1992;14:298-307.

4. Infectious diseases and immunization committee, Canadian Paediatric Society. Group A streptococcus, a re-emergent pathogen. Can Med Assoc J 1993;148:1909-11.

5. Cone LA, Woodard DR, Schlievert PM, Tomory GS. Clinical and bacteriologic observations of a toxic shock-like syndrome due to Streptococcus pyogenes. N Engl J Med 1987;317:146-9.

6. Banter T, Dascal A, Carroll K, Curley FJ. Toxic strep syndrome, a manifestation of group A streptococcal infection. Arch Intern Med 1988;148:1421-4.

7. Stevens DL, Tanner MH, Winship J, et al. Severe group A streptococcal infections associated with a toxic shock-like syndrome and scarlet fever toxin A. N Engl J Med 1989;321:1-7.

8. Martin PR, Holby EA. Streptococcal serogroup A epidemic in Norway 1987-1988. Scand J Inf Dis 1990;22:421-9.

9. Centers for Disease Control. Group A beta-hemolytic streptococcal bacteremia - Colorado, 1989. MMWR 1990;39:3-11.

10. Invasive streptococcal disease in British Columbia; Severe group A streptococcal disease - Toronto, Ontario. Can Dis Wkly Rep 1990;16:257-64.

11. Centers for Disease Control. Nursing home outbreaks of invasive group A streptococcal infections - Illinois, Kansas, North Carolina, and Texas. MMWR 1990;39:577-8.

12. Wheeler MC, Roe MH, Kaplan EL, Schlievert PM, Todd JK. Outbreak of group A streptococcus septicemia in children. JAMA 1991;266:533-7.

13. Hoge CW, Schwartz B, Talkington DF, Breiman RF, MacNeill EM, Englender SJ. The changing epidemiology of invasive group A streptococcal infections and the emergence of streptococcal toxic shock-like syndrome. JAMA 1993;269:384-9.

14. Demers B, Simor AE, Vellend H, et al. Severe invasive group A streptococcal infections in Ontario, Canada: 1987-1991. Clin Infect Dis 1993;16:792-800.

15. Wood TF, Potter MA, Jonasson 0. Streptococcal toxic shock-like syndrome. The importance of surgical intervention. Ann Surg $1993 ; 217: 109-14$

16. Jamieson FB, Green K, Low DE, et al. A cluster of surgical wound infections due to unrelated strains of group A streptococci. Infect Control Hosp Epidemiol 1993;14:265-7.

17. Robinson JH, Kehoe MA. Group A streptococcal M proteins: virulence factors and protective antigens. Immunol Today 1992;13:362-7.

18. National Centre for Streptococcus. Annual report for April 1, 1993 to March 31, 1994.

19. Johnson LP, L'Italien JJ, Schlievert PM. Streptococcal pyrogenic exotoxin type A (scarlet fever toxin) is related to Staphylococcus aureus enterotoxin B. Mol Gen Genet 1986;203:354-6.

20. Willoughby B, Greenberg RN. The toxic shock syndrome and streptococcal pyrogenic exotoxins. Ann Intern Med 1983;98:559.

21. Aerobic and facultative gram positive cocci. In: Woods GL, Gutierrez Y, eds. Diagnostic Pathology of Infectious Diseases. Philadelphia: Lea \& Febiger, 1993:225-7.

22. Quintiliani R, Engh GA. Overwhelming sepsis associated with group A beta-hemolytic streptococci. J Bone Joint Surg 1971;53:1391-9.

23. Schwartz B, Ussery XT. Group A streptoccal outbreaks in nursing homes. Infect Control Hosp Epidemiol 1992;13:742-7.

24. Stevens DL, Gibbons AE, Bergstrom R, Winn V. The eagle effect revisited, efficacy of clindamycin, erythromycin, and penicillin in the treatment of streptococcal myositis. J Infect Dis 1988;158:23-8.

25. Gemmel CB, Peterson PK, Schmelin D, et al. Potentiation of opsonization and phagocytosis of Streptococcus pyogenes following growth in the presence of clindamycin. J Clin Invest 1981;67:1249-56. 